\title{
Supplemental Multilayer Insulation Research Facility
}

P.J. Dempsey and R.J. Stochl

Lewis Research Center

Cleveland, Ohio

Prepared for the

1995 Cryogenic Engineering Conference

sponsored by Centennial Conferences

Columbus, Ohio, July 17-21, 1995

National Aeronautics and

Space Administration 


\title{
SUPPLEMENTAL MULTILAYER INSULATION RESEARCH FACILITY
}

\author{
P. J. Dempsey and R. J. Stochl \\ National Aeronautics and Space Administration \\ Lewis Research Center \\ Cleveland, Ohio, 44135, U.S.A.
}

\begin{abstract}
SUMMARY
The Supplemental Multilayer Insulation Research Facility (SMIRF) provides a small scale test bed for conducting cryogenic experiments in a vacuum environment. The facility vacuum system is capable of simulating a Space Shuttle launch pressure profile as well as providing a steady space vacuum environment of $1.3 \times 10^{-4} \mathrm{~N} / \mathrm{m}^{2}$ ( $1 \times 10^{-6}$ torr). Warm side boundary temperatures can be maintained constant between $111 \mathrm{~K}(200 \mathrm{R})$ and $361 \mathrm{~K}(650 \mathrm{R})$ using a temperature controlled shroud. The shroud can also simulate a typical lunar day-night temperature profile. The test hardware consists of a cryogenic calorimeter supported by the lid of the vacuum chamber. A $0.45 \mathrm{~m}^{3}(120$ gal $)$ vacuum jacketed storage/supply tank is available for conditioning the cryogen prior to use in the calorimeter. The facility was initially designed to evaluate the thermal performance of insulation systems for long-term storage in space. The facility has recently been used to evaluate the performance of various new insulation systems for $\mathrm{LH}_{2}$ and $\mathrm{LN}_{2}$ ground storage dewars.
\end{abstract}

\section{INTRODUCTION}

SMIRF is a unique facility for ground based liquid hydrogen, liquid nitrogen, and vacuum experimentation. Tests that require vacuum and cryogenic capabilities of all types can be performed in this facility. The facility was designed to evaluate thermal performance of cryogenic insulation systems for long-term storage in space. The facility can simulate the pressure history of a shuttle launch, the pressure and temperature history on the lunar surface, and the pressure and temperature of space. SMIRF has most recently been used to evaluate various ground based insulation systems to be used by a commercial dewar manufacturer. This paper describes the SMIRF test facility and its capabilities.

\section{DESCRIPTION OF FACILITY}

\section{General}

The test facility (figure 1) is located in building 204 of the South 40 area of NASA Lewis Research Center. The steel frame building consists of a control room, shop, test area, and a basement under the test area. The building is surrounded on three sides by $4.6 \mathrm{~m}(15 \mathrm{ft})$ earthen mounds. The control room is separated from the shop by a $0.4 \mathrm{~m}(1.3 \mathrm{ft})$ thick concrete wall. The shop in turn is separated from the test area by a $20.3 \mathrm{~cm}(8 \mathrm{in}$.) thick concrete block wall. The

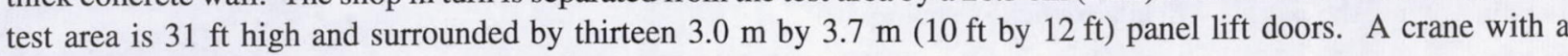
$1814 \mathrm{~kg}(4000 \mathrm{lb}) 6 \mathrm{~m}(20 \mathrm{ft})$ lift capacity is located in the test area.

\section{Vacuum System}

A 304 stainless steel cylindrical vacuum chamber is located at ground level in the test area. The chamber is approximately $250 \mathrm{~cm}(98.3 \mathrm{in}$.) high by $181 \mathrm{~cm}(71.3 \mathrm{in}$.) in diameter with a dished lid and bottom (figure 2). A mezzanine level allows access to the chamber and lid. Three diffusion pumps and 5 mechanical vacuum pumps provide the required vacuum capability. Four mechanical pumps are used as roughing pumps to evacuate the chamber. The fifth pump is used as a backing pump for the diffusion pumps. The exhaust line from the pumps is outside of the building and $4.6 \mathrm{~m}(15 \mathrm{ft})$ above the roofline. The total capacity of the roughing pumps is $33.4 \mathrm{~m}^{3} / \mathrm{min}\left(1180 \mathrm{ft}^{3} / \mathrm{min}\right)$. 


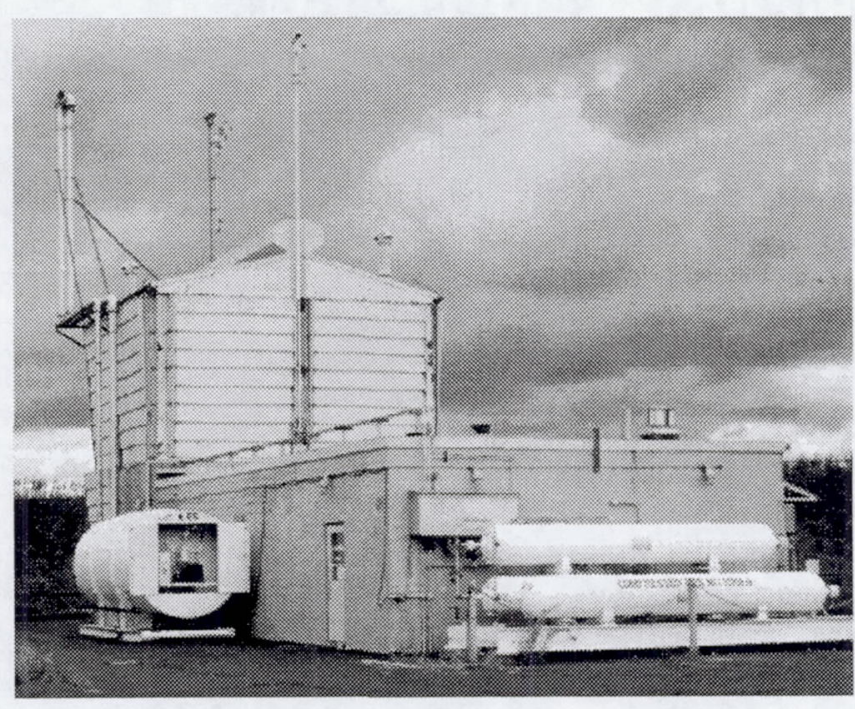

Figure 1.-Supplemental multilayer insulation research facility.

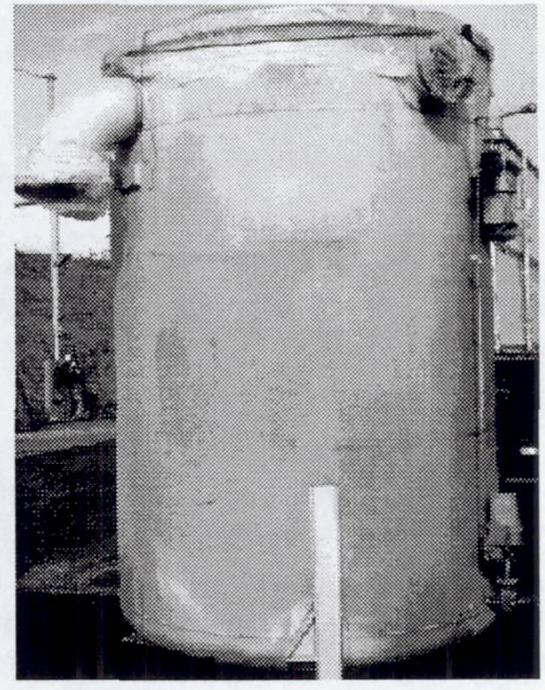

Figure 2.-Vacuum chamber.

Each of the mechanical vacuum pumps are isolated from the vacuum line by a remote operated vacuum gate valve. The vacuum system is configured such that one pump can be used to vacuum purge the test article and $\mathrm{LH}_{2}$ supply lines. All four of the vacuum system pumps can be used to pump down the vacuum chamber. Thermocouple vacuum gages are installed on the inlet to the vacuum pumps to measure inlet pressure. A thermocouple is installed in the pump oil reservoir to measure oil temperature. Flow switches verify cooling water is supplied to the pumps.

A water chiller provides cooling water for the pumps. The water chiller is a self-contained unit consisting of a reservoir chiller and pump. The reservoir has a capacity of $0.053 \mathrm{~m}^{3}(14 \mathrm{gal})$ and contains a $50 / 50$ water glycol solution. The chiller has a heat rejection capability of $53 \mathrm{~kW}$.

Three NRC diffusion pumps are attached directly to the vacuum chamber. The displacement of each pump is 4000 liters/sec. Each diffusion pumps is isolated from the vacuum chamber by a $25.4 \mathrm{~cm}(10 \mathrm{in}$.) gate valve.

The diffusion pumps are equipped with cryotraps. The $\mathrm{LN}_{2}$ filled cryotraps trap (by freezing) any oil from the diffusion pumps which may back stream into the vacuum chamber. The $\mathrm{LN}_{2}$ level in the cryotrap is controlled by a closed loop level controller.

The three diffusion pumps are backed up by a mechanical vacuum pump located in the basement of the test area. $\mathrm{A} \mathrm{GN}_{2}$ gas ballast valve is used on the pump to prevent contamination of the oil reservoir. A thermocouple vacuum gage is installed on the inlet to the vacuum pump to measure inlet pressure.

Each of the diffusion pumps can be isolated from the roughing pumps. In the event of a failure of the roughing pump it is possible to switch to one of the other three mechanical pumps to back the diffusion pumps.

Flow switches on the diffusion pumps and mechanical backing pump verify sufficient cooling water is provided to the pumps. Thermocouples on the diffusion pump heaters indicate if the heaters malfunction. A thermocouple is also installed in the oil reservoir of the backing pump. If any of the temperature sensors or flow switches are outside the pump operating range, the pumps will automatically shutdown.

\section{Shroud System}

A temperature controlled shroud is located inside the vacuum chamber between the vacuum chamber wall and the research article. The purpose of the shroud is to provide a known radiative background temperature for the research article. The shroud can be controlled between $111 \mathrm{~K}(200 \mathrm{R})$ and $361 \mathrm{~K}(650 \mathrm{R})$. The shroud control system is also capable of producing a temperature profile over this range to simulate a lunar day. Temperature ramping capabilities are at least $0.17 \mathrm{~K}$ per minute over the entire range. Shroud temperature top to bottom can be controlled within $\pm 3.0 \mathrm{~K}$ over the entire operating range.

The shroud is made of aluminum finned tubes that are attached to an upper and lower manifold. The shroud is shown on figure 3 . The emissivity of the inner and outer surfaces of the shroud is less than 0.1 . Two removable shields 
(one end attached to the shroud) are installed between the shroud and the test article. The shields are used to shield the test article from heat sources other than the shroud. The shroud is designed for operation at $1.3 \times 10^{-4} \mathrm{~N} / \mathrm{m}^{2}\left(1 \times 10^{-6}\right.$ torr $)$.

The temperature of the shroud is maintained by recirculating thermally conditioned $\mathrm{GN}_{2}$ through the finned tubes. The shroud temperature is controlled at a desired value by a programmable controller which compares the input value from a thermocouple located on the shroud with the desired set temperature. Based on this temperature measurement, the $\mathrm{GN}_{2}$ will either be heated or cooled. Heating is achieved by a $5 \mathrm{~kW}$ electric immersion heater. The incoloy heater is enclosed in a stainless steel housing. The heater transfers heat by forced convection directly to the gas stream. Cooling is achieved by an $\mathrm{LN}_{2}$ to $\mathrm{GN}_{2}$ heat exchanger. A $14.2 \mathrm{~m}^{3} / \mathrm{min}\left(500 \mathrm{ft}^{3} / \mathrm{min}\right)$ blower with a brushless motor is used to recirculate $\mathrm{N}_{2}$. The blower is water cooled using the chilled water system.

\section{Cryogenic Supply System}

The cryogenic supply system consists of a roadable dewar, vacuum jacketed transfer lines, vent systems for the dewars, and a $0.45 \mathrm{~m}^{3}$ (120 gal) vacuum jacketed supply tank. The dewars are connected to the supply tank by a vacuum jacketed transfer line. Vacuum jacketed control valves control the flow to the supply tank. Dewar connections are made using bayonet fittings in the field. Each section of the vacuum jacketed piping is equipped with a combination pumpout, vacuum gaging, and pressure relief port.

A $0.45 \mathrm{~m}^{3}(120 \mathrm{gal})$ supply tank is used to supply cryogens to the test article. The tank is a double walled vacuum jacketed pressure vessel made of 304 stainless steel. The inside diameter is $0.6 \mathrm{~m}(2 \mathrm{ft})$ and the height is $2.4 \mathrm{~m}(8 \mathrm{ft})$. Reflective multilayer gettering materials are installed in the vacuum space. From the supply tank the fluid can enter the chamber through any or all of four separate fill lines.

\section{Cryogenic Vent System}

There are three vent lines available from the chamber, one $5.0 \mathrm{~cm}(2 \mathrm{in}$.) and two $2.5 \mathrm{~cm}(1 \mathrm{in}$.) lines. All three

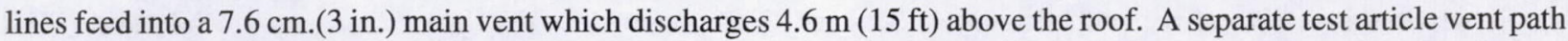
is required when evaluating insulation system thermal performance (boil-off). This is to prevent pressure disturbances in the other tanks from affecting the pressure controls system of the test tank.

\section{Liquid Nitrogen System}

The liquid nitrogen system consists of a $8 \mathrm{~m}^{3}(2100$ gal) roadable dewar $(\mathrm{N}-65)$, flexible vacuum jacketed transfer lines and a vent system for the dewar. The dewar is equipped with a burst disc that relieves at $363 \mathrm{KPa}(38 \mathrm{psig})$. The liquid nitrogen dewar is located on the west side of building 204. The main $\mathrm{LN}_{2}$ vent discharges into a stainless steel drum with a level sensor installed in the top. If the level sensor indicates liquid nitrogen, the main $\mathrm{LN}_{2}$ supply valve is automatically closed. This is to prevent a $\mathrm{LN}_{2}$ spill in the area.

$\mathrm{LN}_{2}$ is provided to the cryotraps on the diffusion pump inlet valves. The $\mathrm{LN}_{2}$ level in the cryotrap is controlled by a closed loop level controller. $\mathrm{LN}_{2}$ is also used in the shroud temperature control system.

\section{Gaseous Helium System}

GHe is used at SMIRF to purge the $\mathrm{LH}_{2}$ system and the vacuum chamber. The facility is supplied by a $16,649 \mathrm{KPa}(2400 \mathrm{psig}), 1982 \mathrm{~m}^{3}\left(70,000 \mathrm{ft}^{3}\right)$ tube trailer. GHe pressure is regulated to $170 \mathrm{KPa}(10 \mathrm{psig})$ using two pressure regulators in series. If pressure of the main supply falls below $3549 \mathrm{KPa}(500 \mathrm{psig})$, the supply automatically switches to two auxiliary $3.0 \mathrm{~m}^{3}\left(106 \mathrm{ft}^{3}\right), 14,581 \mathrm{KPa}(2100 \mathrm{psig})$ tubers.

\section{Gaseous Nitrogen System}

$\mathrm{GN}_{2}$ is used for valve operator pressure, for the gas ballast supply, and for purging vent lines. $\mathrm{GN}_{2}$ is also used to purge electrical boxes which contain components that are not rated for Class I, Division 2, Group B service per the NEC. 
The main $\mathrm{GN}_{2}$ supply is from a $8.8 \mathrm{~m}^{3}\left(310 \mathrm{ft}^{3}\right), 16,649 \mathrm{KPa}(2400 \mathrm{psig})$ storage tuber. If the supply pressure from this main tuber falls below $3549 \mathrm{KPa}(500 \mathrm{psig})$, supply automatically switches to two auxiliary $3.0 \mathrm{~m}^{3}\left(106 \mathrm{ft}^{3}\right)$, $14,581 \mathrm{KPa}(2100 \mathrm{psig})$ tubers. The supply pressure is regulated down to $963 \mathrm{KPa}(125 \mathrm{psig}), 274 \mathrm{KPa}(25 \mathrm{psig})$, and $170 \mathrm{KPa}(10 \mathrm{psig})$ for the various operational usages.

\section{Water System}

A closed loop water chiller, operating at $289 \mathrm{~K}(520 \mathrm{R})$ supplies cooling water to the vacuum pumps, diffusion pumps, and shroud blower. The water chiller consists of a reservoir, a pump, and a heat pump type device for rejection of heat. The reservoir is filled with a 50/50 mixture of glycol and water to prevent freezing during winter months.

The chiller is equipped with temperature switches that shut down the compressor if the water temperature is less than $278 \mathrm{~K}(501 \mathrm{R})$ and shut down the entire unit if the water temperature exceeds $304 \mathrm{~K}(548 \mathrm{R})$. Pressure switches shut down the compressor and discharge fans if refrigeration pressure is less than $136 \mathrm{KPa}(5 \mathrm{psig})$ and shut down the entire unit if refrigeration pressure is greater than $2790 \mathrm{KPa}(390 \mathrm{psig})$. A pressure switch on the compressor shuts down the compressor and discharge fans if pressure is less than $163 \mathrm{KPa}(9 \mathrm{psig})$.

\section{Electrical Systems}

All electrical components in the building are rated for Class I, Division 2, Group B service per the NEC or enclosed in nitrogen purged cabinets. Purge pressure is verified using a pressure switch that alarms if the pressure of a cabinet is less than $0.037 \mathrm{KPa}\left(0.15\right.$ in. of $\left.\mathrm{H}_{2} \mathrm{O}\right)$.

Instrumentation cables run through the test area wall to signal conditioning in the shop area, then through an underground tray to the control room. Control cables run from the test area to the control room through the underground trays. Power cables run through the test area wall and control room wall. All penetrations are sealed at the test area eliminating any paths for the hydrogen to travel from the test area to the control room.

Hydrogen detectors are installed in the test area ceiling and basement. The $\mathrm{H}_{2}$ detectors are set to alarm at $20 \%$ and $40 \%$ of the lower flammable limit (LFL) of $\mathrm{H}_{2}$ in air. The hydrogen detectors alarm in the control room at $20 \%$ (LFL), in both the control room and fire station at $40 \%$ (LFL). Smoke detectors are installed in the control room and shop area. The smoke detectors alarm in both the control room and fire station when smoke is detected.

SMIRF operates with a Gould Modicon 984 programmable logic controller. The controller is used to control facility interlocks, permissives, and shutdowns.

\section{Calorimeter}

The calorimeter is used to provide a constant heat sink temperature during the evaluation of thermal performance of insulation systems. The boil-off from the calorimeter is used to determine the heat flux through the insulation.

The calorimeter, shown in figure 4, consists of three separate $76.2 \mathrm{~cm}$ (30 in.) diameter tanks. The center, or measure tank, is located between two guard tanks. The purpose of the guard tanks is to eliminate heat flow into the measure tank through its two ends. The tanks are constructed of $1.3 \mathrm{~cm}(0.5$ in.) thick 1100 alloy aluminum.

The measure and guard tanks are supported through their centers by a stainless steel tube. During a test this tube is filled with the same cryogen that is in the tanks. This is to prevent conduction or radiation from reaching the measure tank. Insulation systems are placed and supported between two G-10 rings near the ends of each guard tank.

\section{Calorimeter Tank Pressure Control}

The determination of insulation thermal performance (heat flux) by measuring the boil-off from the measure tank requires precise pressure control of the measure tank. The tank pressure, $114 \mathrm{KPa}(16.5 \mathrm{psia})$, is controlled by regulating boil-off flow. The measure tank control system consists of four parallel pneumatic control valves, a controller, a $6.8 \mathrm{KPa}(1 \mathrm{psid})$ pressure transducer, and a constant pressure reference. The control system is sized to measure flows 


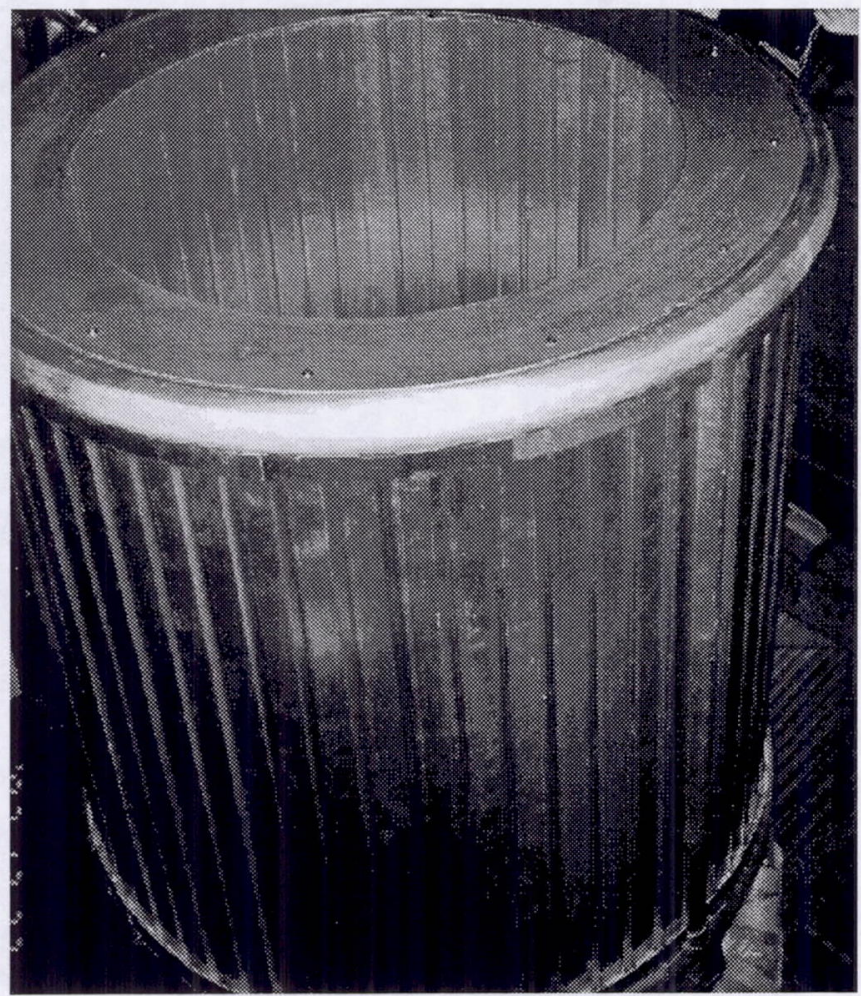

Figure 3.-Temperature controlled shroud.

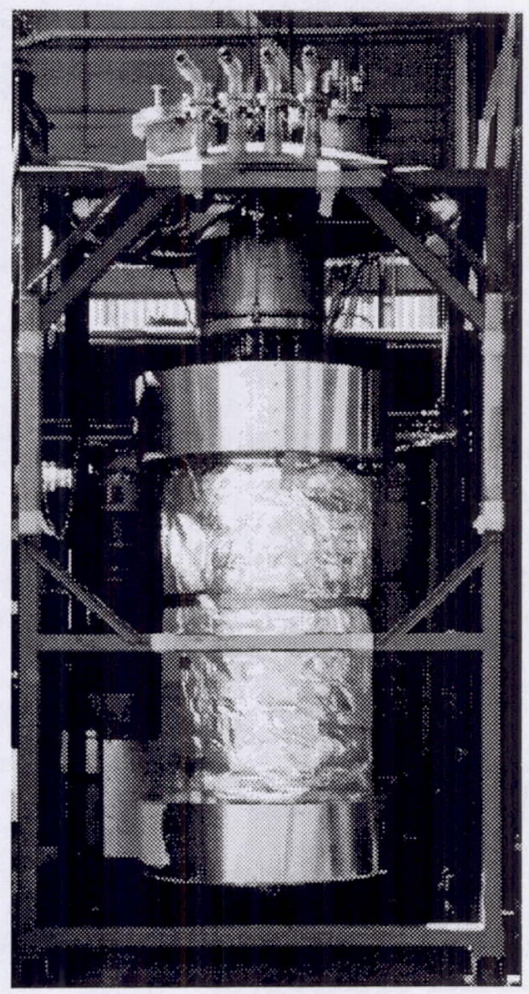

Figure 4.-Calorimeter.

from $0.00056 \mathrm{~m}^{3} / \mathrm{hr}$ to $90.6 \mathrm{~m}^{3} / \mathrm{hr}\left(0.02 \mathrm{ft}^{3} / \mathrm{hr}\right.$ to $\left.3200 \mathrm{ft}^{3} / \mathrm{hr}\right)$ and maintain measure tank pressure to within $+0.14 \mathrm{KPa}$ (+ 0.02 psia). The measure tank boil-off is measured by one or more of a series of five flowmeters.

The two guard tanks have to be maintained at a slightly higher temperature and therefore higher pressure of $117 \mathrm{KPa}(17.0 \mathrm{psia})$ to prevent the condensation of the measure tank boil-off as it passes through the upper guard tank. This is achieved through another set of pneumatic control valves, controller, and a $34 \mathrm{KPa}(5 \mathrm{psid})$ pressure transducer referenced to the same constant pressure volume as the measure tank. This guard tank pressure can be maintained to within $+2.1 \mathrm{KPa}(+0.3 \mathrm{psia})$.

\section{Accomplishments/Plans}

To date this facility has been used to evaluate the performance of seven different insulation systems. Three were evaluated using $\mathrm{LH}_{2}$ in the calorimeter and four used $\mathrm{LN}_{2}$. All tests were successful.

Future plans for this facility include; a program to evaluate the venting characteristics of MLI insulation systems during rapid pressure decays, developing concepts to minimize heat transfer through insulation penetrations such as tank feed and vent lines and tank support members, measuring the thermal permeability of composite material, and demonstrating a propellant liquefaction and storage system in a Mars environment. 


\begin{tabular}{|c|c|c|c|}
\hline \multicolumn{3}{|c|}{ REPORT DOCUMENTATION PAGE } & $\begin{array}{l}\text { Form Approved } \\
\text { OMB No. 0704-0188 }\end{array}$ \\
\hline \multicolumn{4}{|c|}{ 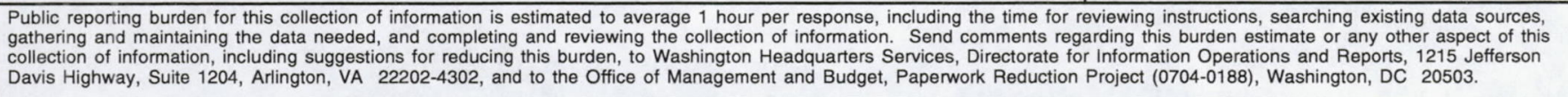 } \\
\hline 1. AGENCY USE ONLY (Leave blank) & $\begin{array}{r}\text { 2. REPORT DATE } \\
\text { July } 1995 \\
\end{array}$ & \multicolumn{2}{|c|}{$\begin{array}{l}\text { 3. REPORT TYPE AND DATES COVERED } \\
\text { Technical Memorandum }\end{array}$} \\
\hline \multicolumn{3}{|c|}{$\begin{array}{l}\text { 4. TITLE AND SUBTITLE } \\
\text { Supplemental Multilayer Insulation Research Facility }\end{array}$} & 5. FUNDING NUMBERS \\
\hline P.J. Dempsey and R.J. Stochl & hl & & WU-243-30-07 \\
\hline \multicolumn{3}{|c|}{$\begin{array}{l}\text { National Aeronautics and Space } \\
\text { Lewis Research Center } \\
\text { Cleveland, Ohio } 44135-3191\end{array}$} & E-9766 \\
\hline \multicolumn{3}{|c|}{ 9. SPONSORING/MONITORING AGENCY NAME(S) AND ADDRESS(ES) } & NASA TM-106991 \\
\hline \multicolumn{4}{|c|}{$\begin{array}{l}\text { Prepared for the } 1995 \text { Cryogenic Engineering Conference sponsored by Centennial Conferences, Columbus, Ohio, } \\
\text { July } 17-21,1995 \text {. Responsible person, P.J. Dempsey, organization code } 2840,(216) 433-5700 \text {. }\end{array}$} \\
\hline \multicolumn{3}{|c|}{$\begin{array}{l}\text { 12a. DISTRIBUTION/AVAILABILITY STATEMENT } \\
\text { Unclassified - Unlimited } \\
\text { Subject Category } 20 \\
\text { This publication is available from the NASA Center for Aerospace Information, (301) 621-0390. }\end{array}$} & 12b. DISTRIBUTION CODE \\
\hline \multicolumn{4}{|c|}{$\begin{array}{l}\text { 13. ABSTRACT (Maximum } 200 \text { words) } \\
\text { The Supplemental Multilayer Insulation Research Facility (SMIRF) provides a small scale test bed for conducting } \\
\text { cryogenic experiments in a vacuum environment. The facility vacuum system is capable of simulating a Space Shuttle } \\
\text { launch pressure profile as well as providing a steady space vacuum environment of } 1.3 \times 10^{-4} \mathrm{Newton} / \mathrm{meter}^{2}\left(1 \times 10^{-6}\right. \\
\text { torr). Warm side boundary temperatures can be maintained constant between } 111 \mathrm{~K}(200 \mathrm{R}) \text { and } 361 \mathrm{~K}(650 \mathrm{R}) \text { using a } \\
\text { temperature controlled shroud. The shroud can also simulate a typical lunar day-night temperature profile. The test } \\
\text { hardware consists of a cryogenic calorimeter supported by the lid of the vacuum chamber. A } 0.45 \mathrm{~meter}^{3}(120 \text { gallon) } \\
\text { vacuum jacketed storage/supply tank is available for conditioning the cryogen prior to use in the calorimeter. The facility } \\
\text { was initially designed to evaluate the thermal performance of insulation systems for long-term storage in space. The } \\
\text { facility has recently been used to evaluate the performance of various new insulation systems for } \mathrm{LH}_{2} \text { and } \mathrm{LN}_{2} \text { ground } \\
\text { storage dewars. }\end{array}$} \\
\hline \multirow{2}{*}{$\begin{array}{l}\text { 14. SUBJECT TERMS } \\
\text { Cryogenic test facility }\end{array}$} & & & $\begin{array}{c}\text { 15. NUMBER OF PAGES } \\
7\end{array}$ \\
\hline & & & $\begin{array}{r}\text { 16. PRICE CODE } \\
\text { A02 }\end{array}$ \\
\hline $\begin{array}{l}\text { 17. SECURITY CLASSIFICATION } \\
\text { OF REPORT } \\
\text { Unclassified }\end{array}$ & $\begin{array}{l}\text { 18. SECURITY CLASSIFICATION } \\
\text { OF THIS PAGE } \\
\text { Unclassified }\end{array}$ & $\begin{array}{l}\text { 19. SECURITY CLASSIFICATION } \\
\text { OF ABSTRACT } \\
\text { Unclassified }\end{array}$ & 20. LIMITATION OF ABSTRACT \\
\hline NSN 7540-01-280-5500 & & & $\begin{array}{l}\text { andard Form } 298 \text { (Rev. 2-89) } \\
\text { escribed by ANSI Std. Z39-18 } \\
8-102\end{array}$ \\
\hline
\end{tabular}

